\title{
AN INTRODUCTION TO SOLAR CELL TECHNOLOGY
}

\author{
Kiran Ranabhat* \\ Peoples' Friendship University of Russia, Moscow, Russian Federation \\ Leev Patrikeev \\ Peoples' Friendship University of Russia, Moscow, Russian Federation \\ Aleksandra Antal'evna Revina \\ Peoples' Friendship University of Russia, Moscow, Russian Federation \\ Kirill Andrianov \\ Peoples' Friendship University of Russia, Moscow, Russian Federation \\ Valerii Lapshinsky \\ Frumkin Institute of Physical Chemistry and Electrochemistry of the Russian \\ Academy of Sciences, Moscow, Russian Federation \\ Elena Sofronova \\ Peoples' Friendship University of Russia, Moscow, Russian Federation
}

Solar cells are a promising and potentially important technology and are the future of sustainable energy for the human civilization. This article describes the latest information achievement in the field of solar cells [Solar cell efficiency tables (version 48) containing the latest efficiency of different types of solar cells published on July 2016. The article also contains data related to the worlds' energy and particularly that part which related to the conversion of solar energy into electrical energy. On the basis of these data prospects of solar energy for human and the possible ways of implementing the latest advanced Photovoltaic technology are defined. Also, methods of conversion of solar energy into electricity, working principles and materials used for various types of photovoltaic technology, as well as the global solar market, present cost of solar energy and roadmap of solar energy is presented in this paper. Imagine solar cells installed in cars to absorb solar energy to replace the traditional use of diesel and gas. Using the same principle, cell phones can also be charged by solar energy. There are such a wide variety of applications.

Key words: Solar cell technology; Types of solar cells; Generation of solar cells; Solar cells; Organic Photovoltaic (OPV); Photovoltaic technology (PV); PV market; DSSC (dye-sensitized solar cell)

\section{INTRODUCTION}

This is the time of nanotechnology. But today there is nothing more important than energy, since the lack of energy means a significant obstacle to the present civilization, i.e not enough food, warm shelter and connection to the Internet, including the consumption of nanotechnology products. The development of modern trends of energy demands promising new technologies and even new physical and chemical processes for the establishment and operation of efficient systems to generate, accumulate, transform and transport of energy into its various forms [01]. Although global fossil fuel resources have not yet been exhausted, the negative social, health, and environmental impacts of our current unsustainable patterns of energy use are apparent $[02,03,04,05,06]$. In the future, large-scale alternative methods of producing the vast quantities of energy needed to sustain and enhance our standard of living are necessary $[07,08,09,10]$. If current trends continue, future society will require increased electrical energy. It seems highly probable that greenhouse gas emissions will lead to significant global warming over the next 50 years. Climate change is real and it is happening right now, it is the most urgent threat facing our entire species and we need to work collectively together and stop it. Fortunately, ad- 
vances in science and technology have provided us with several alternative means of producing energy on a sustainable level, such as wind, geothermal, biomass, and solar [11]. Solar is a cleaner, safer investment for our family and business. We can immediately reduce your electricity bill, enjoy energy independence from rising energy costs and increasing carbon dioxide (CO2) emissions, and increase your home or building's value. Solar energy is ready today.

Ever since the Becquerel discovered the first photovoltaic effect in 1839, using solar energy has been a goal in the scientific world. Every hour the energy absorbed by Earth's atmosphere from the sun is more than enough to satisfy global energy needs for an entire year. For this reason, research in the last few decades has exploded to find the most efficient and cost effective solar cells so the world does not remain fossil fuels dependant. PV technology offers a number of significant benefits. Solar power is a renewable resource that is available everywhere in the world. Solar PV technologies are small and highly modular and can be used virtually anywhere, unlike many other electricity generation technologies. Unlike conventional power plants using coal, nuclear, oil and gas, solar PV has no fuel costs and relatively low operation and maintenance (O\&M) costs. Thus, PV will continue to produce power indefinitely (as long as the sun shines). Photovoltaic are truly a sustainable and environmentally friendly method of producing energy. Not only this but it's for free, so why shall we not utilize it.

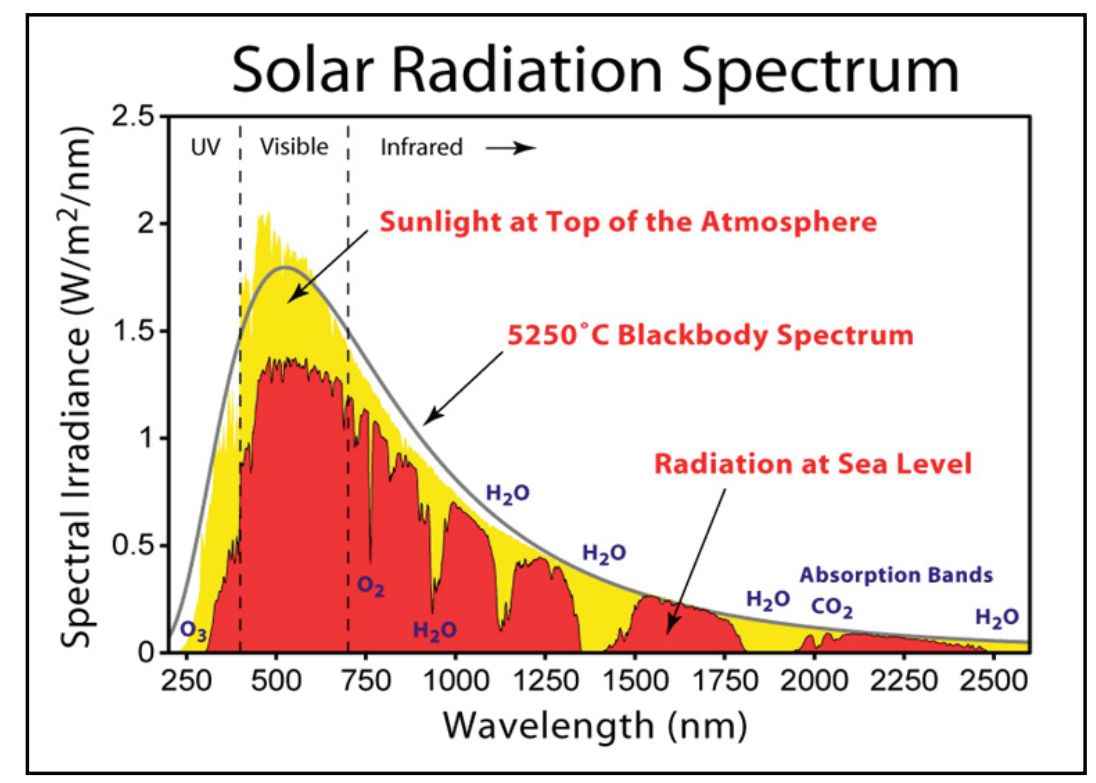

Figure 1: Solar irradiance spectrum above atmosphere and at surface

Solar cells need to absorb a range of energy, which corresponds to the solar spectrum to be efficient. The solar spectrum has a range of $100 \mathrm{~nm}$ to $1 \mathrm{~mm}$, but most of the irradiance occurs between $250 \mathrm{~nm}-2500 \mathrm{~nm}$ (figure 1) with the maximum in the visible region of light $(400-700 \mathrm{~nm})$ for air mass (AM) 0 , which means that the solar cells should strive to absorb as much in visible region of solar spectrum as possible.

The Air Mass is the path length which light takes through the atmosphere normalized to the shortest possible path length (that is, when the sun is directly overhead). The Air Mass quantifies the reduction in the power of light as it passes through the atmosphere and is absorbed by air and dust. The Air Mass is defined as: $A M=\frac{1}{\cos \theta}$,
Where $\theta$ is the angle from the vertical (zenith angle). When the sun is directly overhead, the Air Mass is 1. The purpose of this paper is to explain different types of PV technology present today in the world and to provide the achievements in the field of advanced photovoltaic and photochemical conversion of solar energy into electricity and methods of selection of PV technology according to different criteria (cost of production, the efficiency of solar energy conversion, and others...) Rapid technological developments over the last 20 years coupled with a dramatic decrease in costs of photovoltaic technology have opened the way for large-scale deployment. There are a wide range of $\mathrm{PV}$ cell technologies on the market today, using different types of materials, and an 
even larger number will be available in the future. PV cell technologies are usually classified into three generations, depending on the basic material used and the level of commercial maturity.

\section{FIRST-GENERATION PV TECHNOLOGIES: CRYSTALLINE SILICON CELLS}

Bell Laboratories developed the first silicon solar cell in 1954 with an efficiency of $6 \%$. The earliest commercial silicon traditional solar cells are made from silicon, are currently the most efficient solar cells available for residential use and account for around above $80 \%$ of all the solar panels sold around the world. Silicon solar cells are the most efficient in terms of single cell photovoltaic devices, and silicon is the most abundant element on earth, only second to oxygen. It is a semiconductor material suitable for PV applications, with energy band gap of $1.1 \mathrm{eV}$.

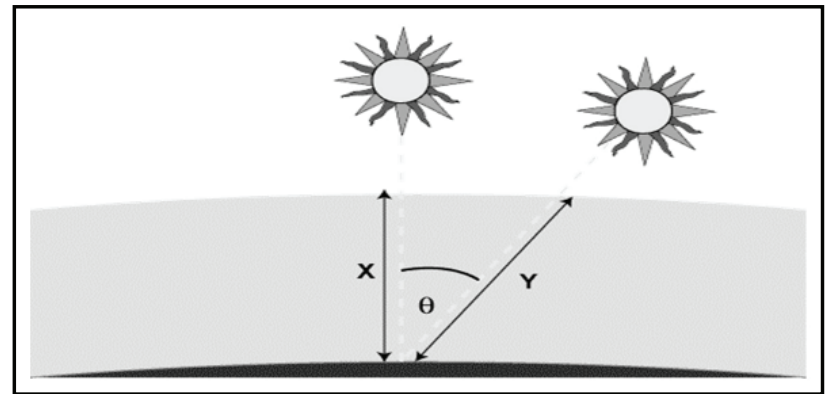

Figure 2: The air mass represents the proportion of atmosphere that the light must pass through before striking the Earth relative to its overhead path length, and is equal to $\mathrm{Y} / \mathrm{X}$

Crystalline silicon cells are classified into three main types depending on how the Si wafers are made. The types are based on the type of silicon used, specifically:

- Monocrystalline (Mono c-Si);

- Polycrystalline (Poly c-Si); and

- Amorphous Silicon Cells.

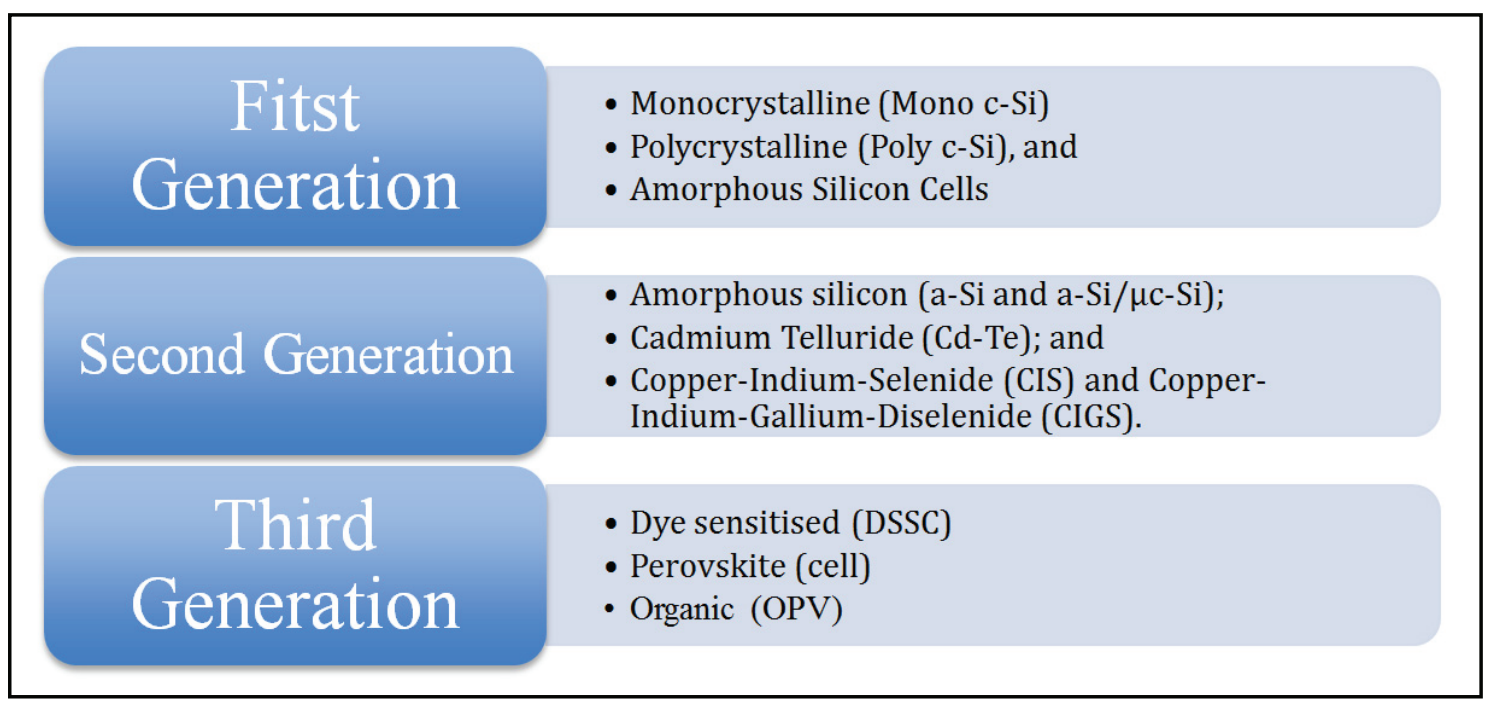

Figure 3: Classification of PV cells

The oldest solar cell technology and still the most popular and efficient are solar cells made from thin wafers of silicon. These are called monocrystalline solar cells. Commercial production of c-Si modules began in 1963 when Sharp Corporation of Japan started producing commercial PV modules and installed a 242-Watt (W) PV (Green, 2001). Compared to the other types of Solar PV, they have a higher efficiency (up to $26 \%$ ) [12], meaning you will obtain more electricity from a given area of panel. Single crystal wafers are made by Czochralski process, as in silicon electronics. It comprises about $30 \%$ of the market. The cost of fabricating single crystalline silicon solar cells is due to the purification pro- cess of bulk.

Policrystalline silicon and amorphous silicon are much less pure than the single crystalline silicon, and most common because they are least expensive. The reason polycrystalline solar panels are less expensive than monocrystalline solar panels, is because of the way the silicon is made. Basically, the molten silicon is poured into a cast instead of being made into a single crystal. The highest recorded efficieny for polycrystalline silicon cell is $21 \%$ [12]. 
Table 1: Conformed terrestrial cell and sub module efficiencies measured under the global AM1.5 spectrum (100W/m2) at $25^{\circ} \mathrm{C}$ (IEC 60904-3: 2008, ASTM G-173-03 global) [12].

\begin{tabular}{|c|c|c|c|c|c|c|c|}
\hline Classification & $\begin{array}{l}\text { Efficiency } \\
(\%)\end{array}$ & $\begin{array}{l}\text { Area } \\
(\mathrm{cm} 2)\end{array}$ & $\begin{array}{l}\text { Voc } \\
\text { (V) }\end{array}$ & $\begin{array}{c}\mathrm{Jsc} \\
(\mathrm{mA} / \mathrm{m} 2)\end{array}$ & $\begin{array}{c}\text { Fill } \\
\text { factor }(\%)\end{array}$ & $\begin{array}{l}\text { Test centre } \\
\text { (Dates) }\end{array}$ & Description \\
\hline \multicolumn{8}{|l|}{ Silicon } \\
\hline Si (crystalline cell) & $25.6 \pm 0.5$ & 143.7 & 0.740 & 41.8 & 82.7 & AIST (2/14) & $\begin{array}{l}\text { Panasonic HIT, } \\
\text { rear junction }\end{array}$ \\
\hline Si (multicrystalline cell) & $21.3 \pm 0.4$ & 242.74 & 0.6678 & 39.80 & 80.0 & $\begin{array}{r}\text { FhG-ISE } \\
(11 / 15)\end{array}$ & Trina Solar \\
\hline Si (thin transfer submodule) & $21.2 \pm 0.4$ & 239.7 & 0.687 & 38.50 & 80.3 & NREL (4/14) & $\begin{array}{l}\text { Solexel }(35 \mu \mathrm{m} \\
\text { thick) }\end{array}$ \\
\hline Si (thin film minimoule) & $10.5 \pm 0.3$ & 94.0 & $0.492 c$ & 29.7 & 72.1 & $\begin{array}{r}\text { FhG-ISE } \\
(8 / 07)\end{array}$ & $\begin{array}{c}\text { CSG Solar }(<2 \\
\mu \mathrm{m} \text { on glass })\end{array}$ \\
\hline \multicolumn{8}{|l|}{ III-V cells } \\
\hline GaAs (thin film cell) & $28.8 \pm 0.9$ & 0.9927 & 1.122 & 29.68 & 86.5 & NREL (5/12) & Alta Devices \\
\hline GaAs (multicrystalline) & $18.4 \pm 0.5$ & 4.011 & 0.994 & 23.2 & 79.7 & $\begin{array}{l}\text { NREL } \\
(11 / 95)\end{array}$ & $\begin{array}{l}\text { RTI, Ge sub- } \\
\text { strate }\end{array}$ \\
\hline InP (crystalline cell) & $22.1 \pm 0.7$ & 4.02 & 0.878 & 29.5 & 85.4 & NREL (4/90) & Spire, epitaxial \\
\hline \multicolumn{8}{|l|}{ Thin Film Chalcogenide } \\
\hline CIGS (cell) & $21 \pm 0.6$ & 0.9927 & 0.757 & 35.70 & 77.6 & $\begin{array}{r}\text { FhG-ISE } \\
(4 / 14)\end{array}$ & Solibro, on glass \\
\hline CIGS (minimodule) & $18.7 \pm 0.6$ & 15.892 & $0.701 \mathrm{c}$ & 35.29 & 75.6 & $\begin{array}{r}\text { FhG-ISE } \\
(9 / 13)\end{array}$ & $\begin{array}{r}\text { Solibro, } 4 \text { serial } \\
\text { cells }\end{array}$ \\
\hline CdTe (cell) & $21.0 \pm 0.4$ & 1.0623 & 0.8759 & 30.25 & 79.4 & $\begin{array}{r}\text { Newport } \\
(8 / 14)\end{array}$ & $\begin{array}{r}\text { First Solar, on } \\
\text { glass }\end{array}$ \\
\hline CZTSSe (cell) & $9.8 \pm 0.2$ & 1.115 & 0.5073 & 31.95 & 60.2 & $\begin{array}{r}\text { Newport } \\
(4 / 16)\end{array}$ & IMRA Europe \\
\hline CZTS (cell) & $7.6 \pm 0.1$ & 1.067 & 0.6585 & 20.43 & 56.7 & NREL (4/16) & UNSW \\
\hline \multicolumn{8}{|l|}{ Amorphous/microcrystalline } \\
\hline Si (amorphous cell) & $10.2 \pm 0.3$ & 1.001 & 0.896 & 16.36 & 69.8 & AIST (7/14) & AIST \\
\hline Si (microcrystalline cell) & $11.8 \pm 0.3$ & 1.044 & 0.548 & 29.39 & 73.1 & AIST (10/14) & AIST \\
\hline \multicolumn{8}{|l|}{ Perovskite } \\
\hline Perovskite (cell) & $19.7 \pm 0.6$ & 0.9917 & 1.104 & 24.67 & 72.3 & $\begin{array}{r}\text { Newport } \\
(3 / 16)\end{array}$ & KRICT/UNIST \\
\hline \multicolumn{8}{|l|}{ Dye sensitised } \\
\hline Dye (cell) & $11.9 \pm 0.4$ & 1.005 & 0.744 & 22.47 & 71.2 & AIST (9/12) & Sharp \\
\hline Dye (minimodule) & $10.7 \pm 0.4$ & 26.55 & $0.754 \mathrm{c}$ & 20.19 & 69.9 & AIST (2/15) & $\begin{array}{r}\text { Sharp, } 7 \text { serial } \\
\text { cells }\end{array}$ \\
\hline Dye (submodule) & $8.8 \pm 0.3$ & 398.8 & $0.697 \mathrm{c}$ & 18.42 & 68.7 & AIST $(9 / 12)$ & $\begin{array}{r}\text { Sharp, } 26 \text { serial } \\
\text { cells }\end{array}$ \\
\hline \multicolumn{8}{|l|}{ Organic } \\
\hline Organic (cell) & $11.2 \pm 0.3$ & 0.992 & 0.780 & 19.30 & 74.2 & AIST (10/15) & Toshiba \\
\hline Organic (minimodule) & $9.7 \pm 0.3$ & 26.14 & 0.806 & 16.47 & 73.2 & AIST (2/15) & $\begin{array}{r}\text { Toshiba ( } 8 \text { se- } \\
\text { ries cells) }\end{array}$ \\
\hline \multicolumn{8}{|l|}{ Multijunction } \\
\hline Five junction cell (bonded) & $38.8 \pm 1.2$ & 1.021 & 4.767 & 9.564 & 85.2 & NREL $(7 / 13)$ & Spectrolab \\
\hline $\operatorname{lnGaP} / G a A s / \operatorname{lnGaAs}$ & $37.9 \pm 1.2$ & 1.047 & 3.065 & 14.27 & 86.7 & AIST (2/13) & Sharp \\
\hline $\begin{array}{l}\text { GalnP/GalnAs/Ge; Si (mini- } \\
\text { module) }\end{array}$ & $34.5 \pm 2$ & 27.83 & 0.999 & $13.3 / 9.1$ & $85.6 / 79.0$ & NREL (4/16) & $\begin{array}{r}\text { UNSW/Azur/ } \\
\text { Trina }\end{array}$ \\
\hline GalnP/GaAs (monolithic) & $31.6 \pm 1.5$ & 0.999 & 2.538 & 14.18 & 87.7 & NREL $(1 / 16)$ & Alta Devices \\
\hline a-Si/nc-Si/nc-Si (thin film) & $13.6 \pm 0.4$ & 1.043 & 1.901 & 9.92 & 72.1 & AIST (1/15) & AIST \\
\hline a-Si/nc-Si (thin film cell) & $12.7 \pm 0.4$ & 1.000 & 1.342 & 13.45 & 70.2 & AIST (10/14) & $\mathrm{Al}$ \\
\hline
\end{tabular}


Silicon solar cells typically have two layers: a positive layer ( $p$-type) and a negative layer ( $n$ type). The positive layer is usually made by doping silicon with boron to create extra holes in the silicon lattice, and he negative layer is usually made by doping silicon with phosphorus to have extra electrons available in the silicon lattice. Working principal for the silicon solar cells is shown in Figure 4.

\section{SECOND-GENERATION PV TECHNOLOGIES: THIN-FILM SOLAR CELLS}

Second-generation solar cells are also known as thin-film solar cells because when compared to crystalline silicon based cells they are made from layers only a few micrometers thick. After more than 20 years of R\&D, thin-film solar cells are beginning to be deployed in significant quantities. Thin-film solar cells could potentially provide lower cost electricity than c-Si wafer-based solar cells.

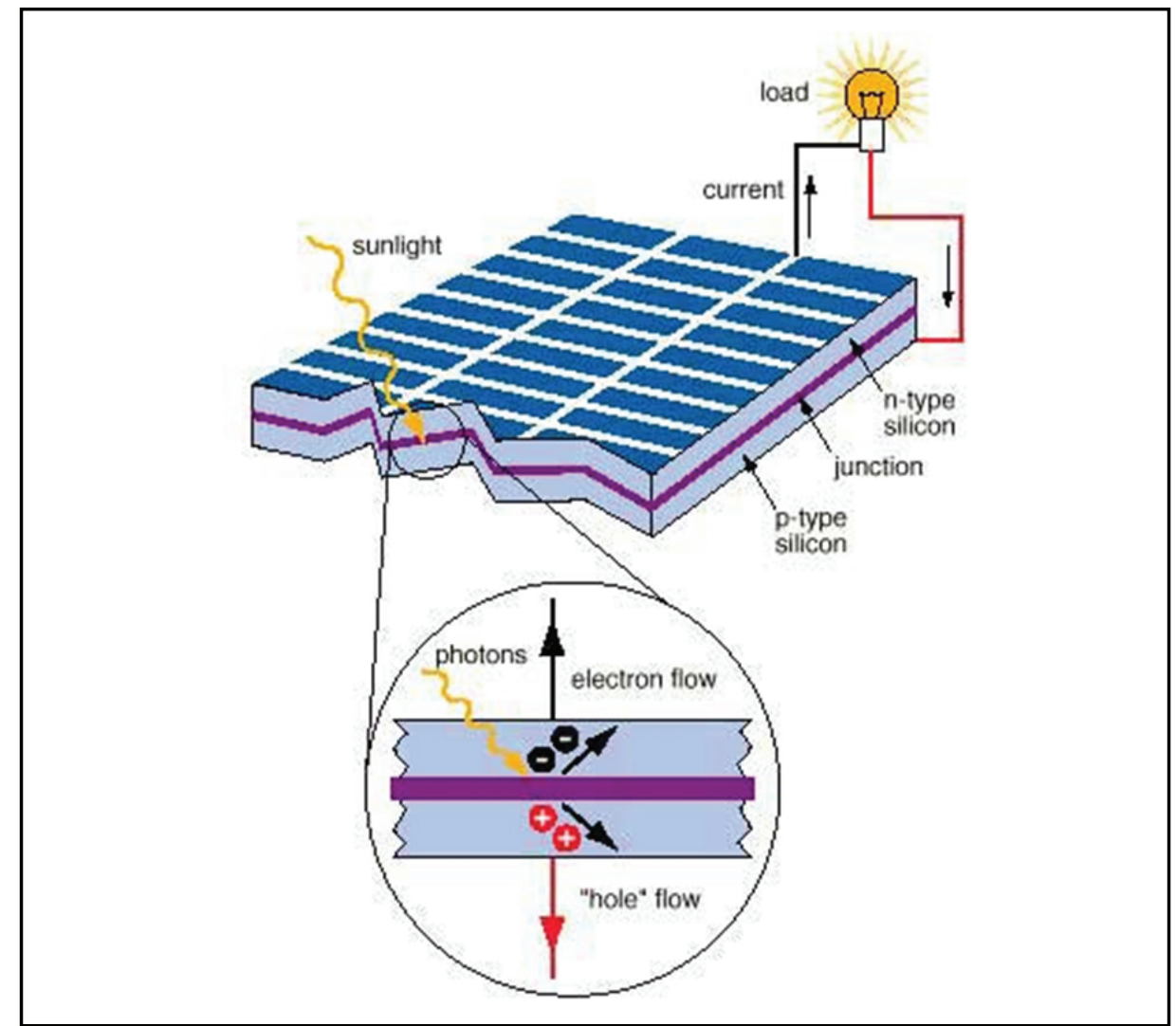

Figure 4: Schematic of the basic structure of a silicon solar cell. Adapted from [22].

Thin-film solar cells are comprised of successive thin layers, just 1 to $4 \mu \mathrm{m}$ thick, of solar cells deposited onto a large, inexpensive substrate such as glass, polymer, or metal. Thin films can be packaged into flexible and lightweight structures, which can be easily integrated into building components (building-integrated PV, BIPV). Second generation of solar cells they account around $20 \%$ of the total panels sold in past year. There are basically three primary types of thinfilm solar cells that have been commercially developed:

- Amorphous silicon (a-Si and a-Si/Mc-Si);

- Cadmium Telluride (Cd-Te); and

- Copper-Indium-Selenide (CIS) and CopperIndium-Gallium-Diselenide (CIGS).
We have not thought about it before, most solar cells used in calculators and many small electronic devices are made from amorphous silicon cells. Instead of growing silicon crystals as is done in making the two previous types of solar cells, silicon is deposited in a very thin layer on to a backing substrate - such as metal, glass or even plastic. One advantage of using very thin layers of silicon is that the panels can be made flexible. The disadvantage of amorphous panels is that they are much less efficient per unit area (up to 12\%) [12].

There are a few fundamental differences between second-generation solar cells and first generation solar cells. The most notable difference is the semiconductor material used in the 
cell has a direct band gap as opposed to the indirect band gap of silicon, but these cells still rely on a p-n junction design. Thin film cells have a top layer called the winder layer made of a large band gap material that absorbs the higher energy photons and a bottom layer called the absorber layer made of a smaller band gap material that absorbs the lower energy photons, which are not absorbed by the window layer. This design allows for an inherently better efficiency. CIGS cells have the highest efficiencies of thin film cells at $21.6 \%$; CdTe cells have an efficiency of $21.4 \%$, and amorphous silicon has an efficiency of $11.8 \%$. Although these thin film solar cells have a lower costs and good efficiencies, they have some drawbacks. Most of the material that these cells are made of are either becoming increasingly rare and more expensive (indium) or are highly toxic (cadmium).

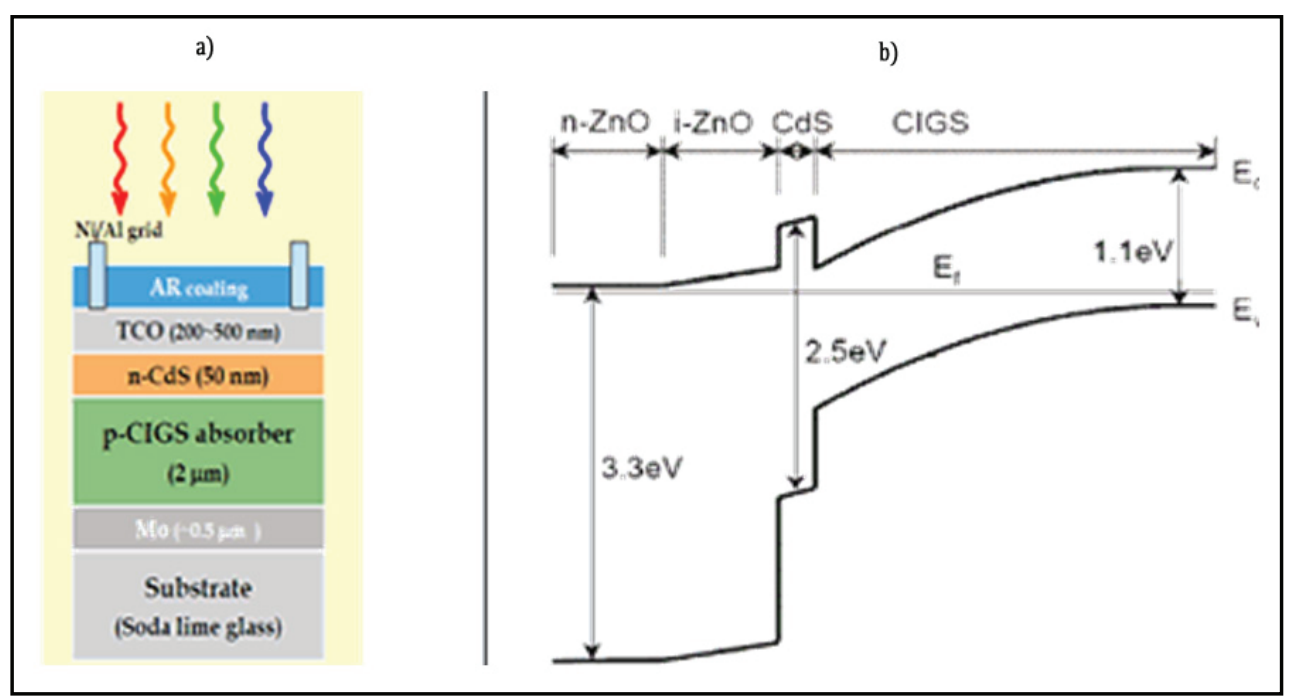

Figure 5: Schematic of the basic structure of a CIGS solar cell (a). CIGS solar cell band diagram (b). [23]

It may take several more years to solve the manufacturing problems and bring the production costs in line with the other leading producers of solar panels. Because of these drawbacks, a different generation of solar cells has been inspired.

\section{THIRD-GENERATION PV TECHNOLOGIES}

Due to high costs of first generation solar cells and toxicity and limited availability of materials for second-generation solar cells, a new generation of solar cells emerged. Currently there is a lot of solar research going on in what is being referred to in the in the industry as Third-generation solar cells. Third generation solar cells are inherently different from the previous two generations because they do not rely on the $p-n$ junction design of the others. This new generation of solar cells are being made from variety of new materials besides silicon, including nanomaterials, silicon wires, solar inks using conventional printing press technologies, organic dyes, and conductive plastics. The goal of course is to improve on the solar cells already commercially available - by mak- ing solar energy more efficient over a wider band of solar energy, less expensive and without any toxicity so it can be used by more and more people, and to develop more and different uses.

Dye-sensitized solar cells are also frequently called Grätzel cells named after the developer. DSSCs separate the absorption of photons from the energy generation. Among various solar cells, dye-sensitized solar cells (DSSCs) demonstrate specific advantages over other photovoltaic devices, because of their high efficiency, low cost, simple fabrication procedures, environmental friendliness, transparency, and good plasticity. Though DSSCs perform well under laboratory conditions relative to other solar cells, parameters such as efficiency, lifetime, and cost determine their commercial applications. The major components of conventional DSSCs include a nanocrystalline semiconductor oxide, a dye sensitizer, a redox electrolyte, and a counter electrode (CE). [13,14] Recently, extensive studies of the individual components of DSSCs have been performed to reduce production costs and to achieve high cell performance. The cell per- 
formance depends on many factors such as surface morphology, particle size, photo-electrode thickness of $\mathrm{TiO} 2$, and the nature of the dye. An overall solar conversion efficiency of more than $12 \%$ has been achieved by employing liquid electrolytes (I-/I-3 redox couple) in DSSCs. How- ever, the use of liquid electrolytes causes many problems in DSSCs such as short-term stability due to organic solvent evaporation and leakage, difficulty in sealing the device, electrode corrosion, and limited solubility of inorganic salts such as $\mathrm{KI}, \mathrm{Nal}$, and Lil $[15,16]$.

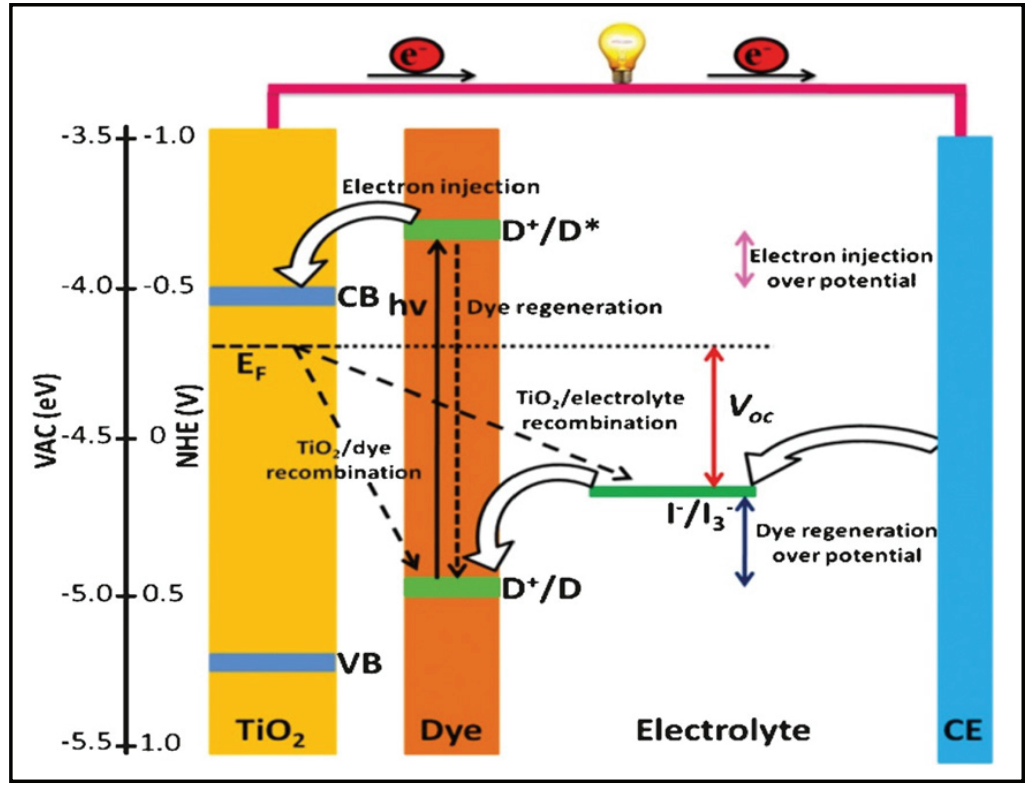

Figure 6: Energy-level diagram of a DSSC. $V A C=$ vacuum energy level, $C B=$ conduction band, $V B=$ valence band

Organic or polymer solar cells were developed to make a more flexible solar cell. Organic or polymer cells are classified as such because the active layers of the cell are made of completely organic materials. These cells can either have abilayer structure or a bulk-heterojunction structure, but the mechanism of both designs is the same. The active layer of organic solar cells is comprised of donor and acceptor materials for charge separation and transportation. Figure 8 illustrates the mechanism of an organic solar cell. Organic solar cells are composed of organic or polymer materials (such as organic polymers or small organic molecules). They are inexpensive, but not very efficient. They are emerging as a niche technology, but their future development is not clear. Their success in recent years has been due to many significant improvements that have led to higher efficiencies. OPV module efficiencies are now in the range $8 \%$ to $10 \%$ for commercial systems. Organic cell production uses high-speed and low- temperature roll-to-roll manufacturing processes and standard printing technologies. As a result, organic solar cells may be able to compete with other PV technologies in some applications, because manufacturing costs are continuing to decline and are expected to reach USD $0.50 / \mathrm{W}$ by 2020 .

In addition to the above-mentioned third-generation technologies, there are a number of novel solar cell technologies under development that rely on using quantum dots/wires, quantum wells, or super lattice technologies. These technologies are likely to be used in concentrating PV technologies where they could achieve very high efficiencies by overcoming the thermodynamic limitations of conventional (crystalline) cells. However, these high efficiency approaches are in the fundamental materials research phase. Furthest from the market are the novel concepts, often incorporating enabling technologies such as nanotechnology, which aim to modify the active layer to better match the solar spectrum.

In recent years, several new thin-film PV technologies have emerged as a result of intense research and development (R\&D) efforts in materials discovery and device engineering. These technologies rely on nanostructured materials, or nanomaterials, which can be rationally engineered to achieve desired optical and electronic properties. While these technologies range in maturity from fundamental materials R\&D to early commercialization and have not yet been 
deployed at large scale, they offer potentially unique device-level properties such as visible transparency, high weight-specific power (watts per gram [W/g]), and novel form factors. These qualities could open the door to novel applications for solar PV [21]

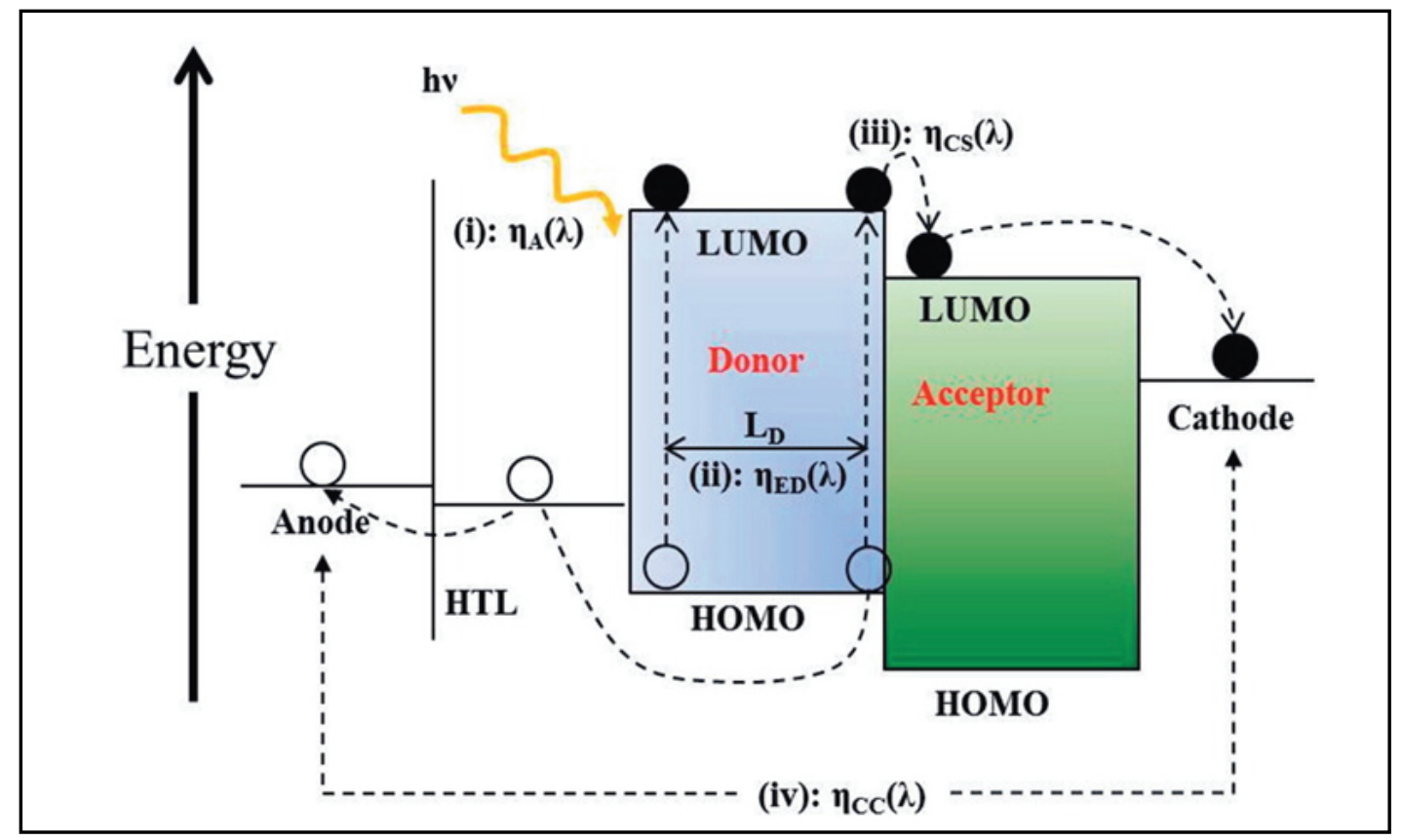

Figure 7: Schematic of the mechanism of an organic solar cell

\section{GLOBAL SOLAR MARKET}

Solar power is essential to the planet's sustainable energy supply. According to the International Energy Agency, it is on the path to becoming the largest source of electricity by 2050 . Solar is a cleaner, safer investment for our family and business. We can immediately reduce your electricity bill, enjoy energy independence from rising energy costs, and increase your home or building's value. Global solar PV installation for 2015 increased $34 \%$ over 2014 numbers, reaching an estimated $59 \mathrm{GW}$ by the end of the year. [GTM research] Thanks to the massive price declines achieved in recent years and continued in 2015, solar power is now broadly recognized as a cost-competitive, reliable and sustainable energy source. In fact, based on its technical characteristics, PV can and should be considered a low risk investment for the financial community today. Its market uptake is strongly dependent on a stable and forward looking regulatory framework that allows for the realization of the full competitive potential of solar power.

In the year $2015,50 \mathrm{Gw}$ of solar power has been connected worldwide. Once again, China, Japan and the United States were the top three markets, followed by the United Kingdom. ( $p$ See Figure
10.) Others in the top 10 for additions were India, Germany, the Republic of Korea, Australia, France and Canada. By end-2015, every continent (except Antarctica) had installed at least 1 $\mathrm{GW}$, and at least 22 countries had $1 \mathrm{GW}$ or more of capacity. The leading national markets were China with $15.2 \mathrm{Gw}$, japan with $11 \mathrm{Gw}$ and the USA with just over $7 \mathrm{Gw}$. Elsewhere in Asia, the largest annual market was India (2 GW), ranking fifth globally for additions and tenth for total capacity. India's year-end capacity was over 5 GW. [17] In parallel, several countries contributed significantly to the market development with Canada, Taiwan, Netherlands and Chilli installing close to $500 \mathrm{MW}$ each. PV is progressing in all regions of the world. The $540 \mathrm{GW}$ mark at global level could be reached in five year's time, with the current speed.

Solar power has shown in these last years its ability to adapt to most climates, system sizes and regulatory frameworks all over the world. The market growth today has brought production capacities closer to a sustainable utilisation rate and therefore, with profitable companies, a new cycle of investment can start in the PV sector. This is because of the expected market growth in several regions. A new cycle of investment can grow in PV sector. 
Solar energy is already economically viable in many applications, and will continue to expand as production continues to increase in scale. Economics of scale will decrease the cost of solar energy while simultaneously facilitating net job creation. In addition, photovoltaic energy production represents an environmentally beneficial and sustainable method of maintaining an energy intensive standard of living, which will enable development without compromising those who will live in the future to do the same. Increasing the efficiency of a photovoltaic device is the aim of many research and development e orts. A higher efficiency produces the same amount of electrical power on a smaller area, i.e. less material is needed. This opens a path for reducing costs and allows for business opportunities. Solar power needs a forward looking investment and market framework just as much as the society and our economies need reliable, clean and sustainable energy sources. Understanding this fact will pave the way for a bright solar PV future, in Europe and globally.

\section{COST OF SOLAR ENERGY}

Solar photovoltaic is already today a low-cost renewable energy technology. Solar power will soon be the cheapest form of electricity in many regions of the world. Depending on annual sunshine, power cost of 4-5 ct/kWh is expected by 2025, reaching 2-4 ct/kWh by 2050 [Agora Energiewende]. Power produced by solar photovoltaic, long known as one of the most expensive renewable energy technologies, is today cost competitive with both wind onshore and power generated by fossil fuels in the world. A power purchase agreement for a $200 \mathrm{MW}$-solar farm in Dubai was recently signed for $5 \mathrm{ct} / \mathrm{kWh}(5.84$ $\$ c t / k W h)$. Projects under construction in Brazil, Uruguay and other countries are reported to produce at costs below $7 \mathrm{ct} / \mathrm{KWh}$.

Solar energy is widely available throughout the world and can contribute to reduced dependence on energy imports. Solar PV involves no greenhouse gas emissions during operation and does not emit other pollutants (such as oxides of sulphur and nitrogen); additionally, it consumes no or little water. The PV industry has experienced a sea change in only five years, with considerable increases in manufacturing capacities. Market prices have been drastically reduced - by factor of five for modules, and by a factor of almost three for systems. The global rate of annual new-built capacities, which was $7 \mathrm{GW}$ in 2009, was 5 times higher in 2013.

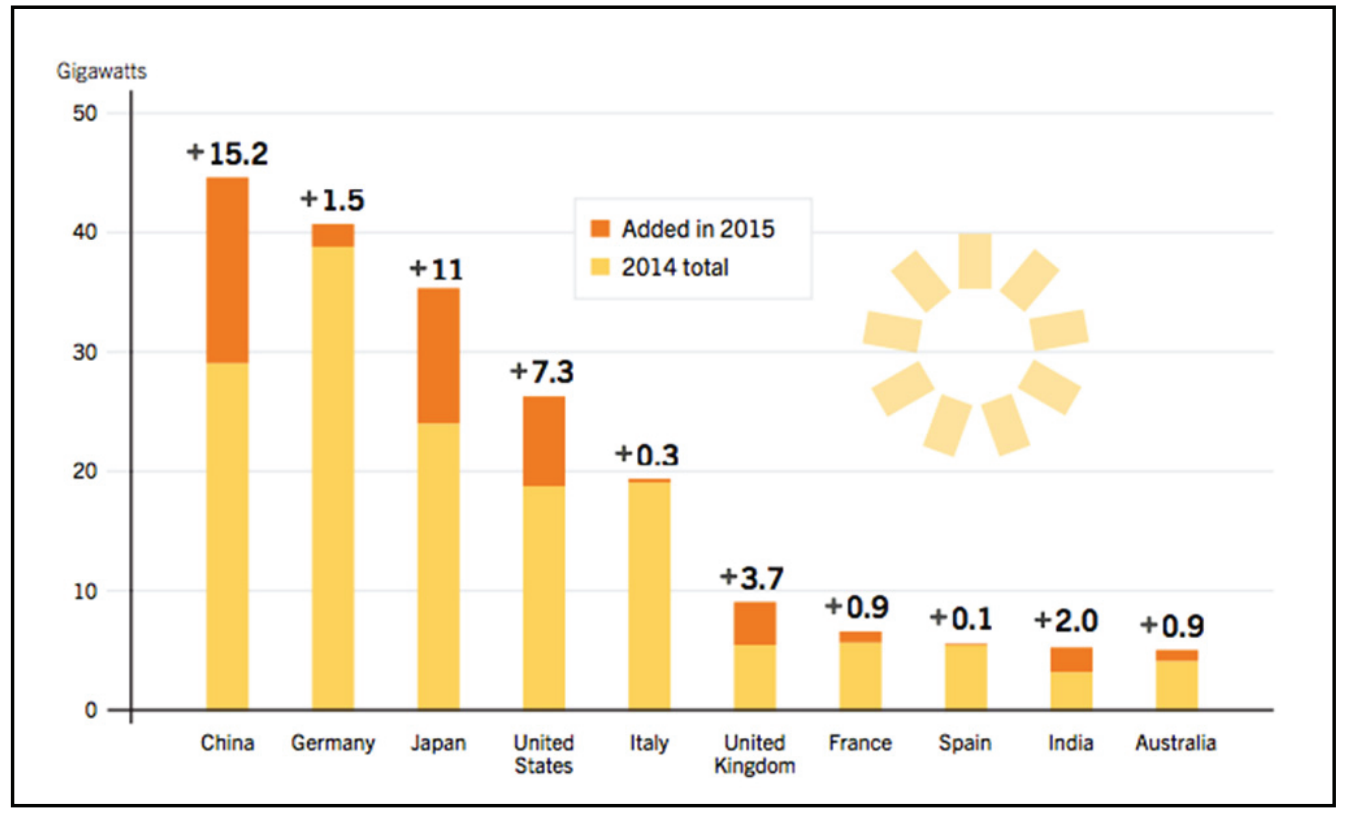

Figure 8. Evolution of global solar PV annual installatalled capacity in [GWp]

\section{SUMMARY}

For human, animals and plants solar energy is equally important. Solar energy is lauded as an inexhaustible fuel source that is pollution and often noise free. Solar photovoltaic technology provides a technologically feasible solution to societies current health and environmental dilemmas posed by the reliance on fossil fuel based power generation. 
Solar energy is already economically viable in many applications, and will continue to expand as production continues to increase in scale. Solar $\mathrm{PV}$ is one of the very few low-carbon energy technologies with very high potential to grow to very large scale. Based on the latest information in PV technology it follows that:

- None industries have grown as fast or as unpredictably as the PV industry in recent years.

- No single PV technology today excels in all three key technical characteristics: high power conversion efficiency, low materials usage, and low manufacturing complexity and cost.
If photovoltaic (PV) devices could be mass produced with printing presses using roll-to-roll (R2R) technology, as if they were newspaper or banknotes, they could be affordable and omnipresent. In recent years, several new PV technologies have emerged and these technologies rely on nanostructured materials, or nanomaterials which can be easily engineered to achieve desired optical and electrical properties which may reach cost and performance targets. Focusing on the unique features, strengths and potential applications of solar PV will help human civilization to identify golden opportunity for future PV technology development and its implementation to meet the future global energy demand.

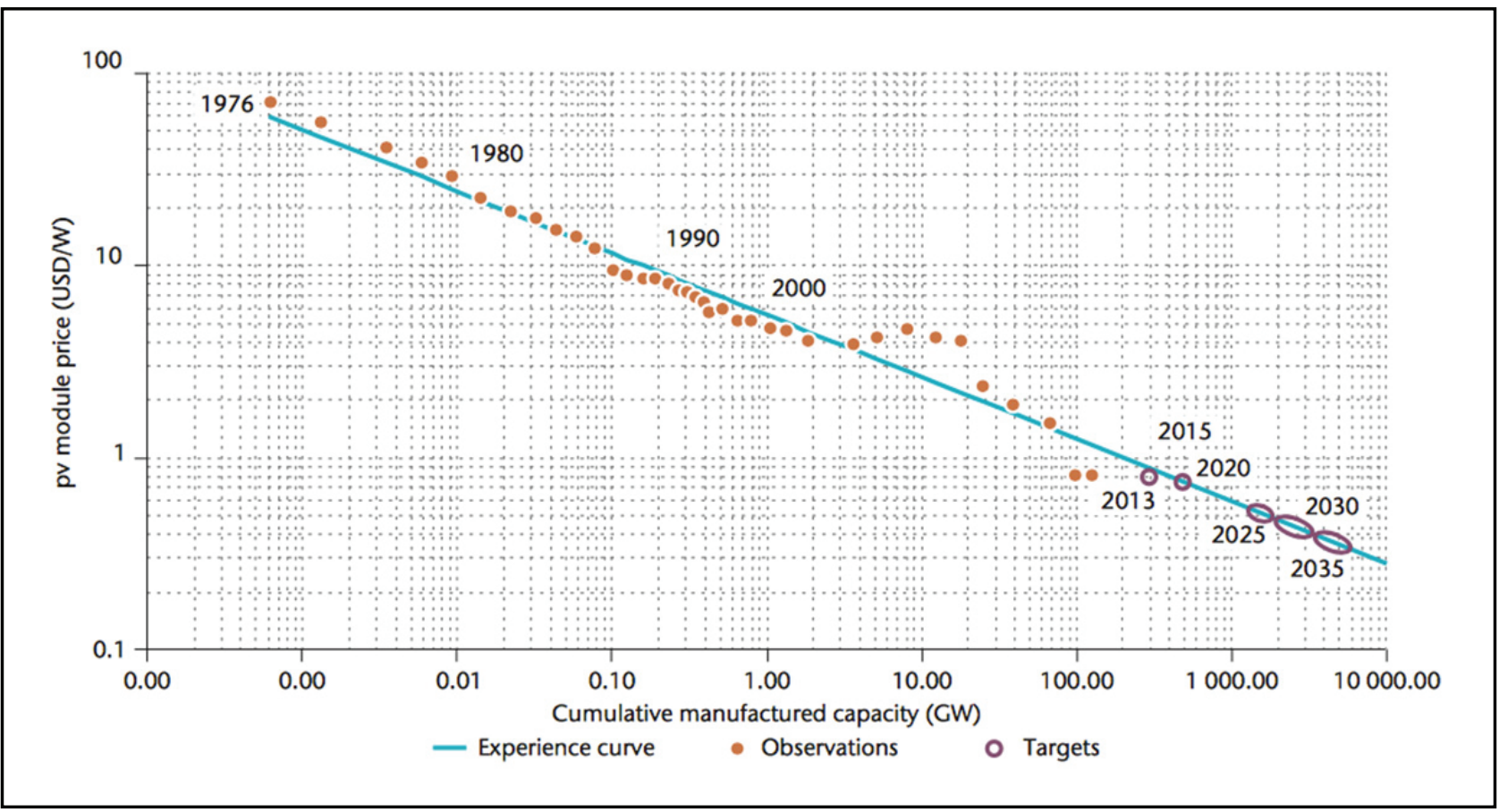

Figure 9: Past modules prices and projection to 2035 based on learning curve [18]

\section{REFERENCES}

1) Mikhailova I. A. Introduction to nanoenergy: tutorial. - M: Moscow Power Engineering Institute "MPEI". Publishing house MPEI, 2011. $-317.1$

2) Keeling $C D$ and Tans P. In: Houghton J, editor, Global Warming: the complbriefing. Cambridge, UK: Cambridge University Press, 1997.

3) Meadows D H, Meadows D I, Randers J, and Behrens III WW. The limits to growth. New York: Universe Books, 1972.

4) Peet J. Energy and the ecological economics of sustainability, Washington, D.C: Island Press, 1992
5) Minger T. Greenhouse glasnost: the crisis of global warming. New York: Institute of Resource Management, 1990.

6) Epstein P R, Haines A, McMichael A J. Canadian Medical Assn Journal 2000, 163(6): 729-734.

7) World's Commission on Environment and Development, Our common future (The Bruntland Report). New York: Oxford University Press, 1987.

8) French $\mathrm{H}$. Vanishing borders: protecting the planet in the age of globalization. New York: W.W. Norton \& Company Inc., 2000

9) Flavin C. Building a bridge to sustainable en- 
ergy, In Brown L. editor, State of the World 1992, New York: Worldwatch Institute and Norton, 1992.

10) Harper P. The end in sight? Some speculations on environmental trends in the twentyfirst century, Futures 2000; 32:361-384.

11) Turner J A. A realizable renewable energy future, Science 1999; 285(5427): 687-689.

12) Green MA, Emery K, Hishikawa $Y$, Warta W, Dunlop ED. Solar cell efficiency tables (Version 48). Progress in Photovoltaics: Research and Applications 2016;

13) M. Wu, X. Lin, Y. Wang, L. Wang, W. Guo, D. Qi, X. Peng, A. Hagfeldt, M. Grätzel, T. Ma, J. Am. Chem. Soc. 2012, 134, 3419-3428.

14) A. Fakharuddin, R. Jose, T. M. Brown, F. F. Santiago, J. Bisquert, Energy Environ. Sci. 2014, 7,3952-3981.

15) B. Munkhbayar, Md. J. Nine, J. Jeoun, M. Ji, H. Jeong, H. Chung, J. Power sources 2013, 203, 207-217.

16) M. K. Nazeeruddin, F. De Angelis, S. Fantacci, A. Selloni, G. Viscardi, P. Liska, S. Ito, B. Takeru, M. Grätzel, J. Am. Chem. Soc. 2005, 127, 16835- 16847.
17) Renewable Energy Network for 21st century (REN21), RENEWABLES 2016 Global Status Report.

18) International Energy Agency (IEA) // Technology Roadmap Solar Photovoltaic Energy, 2014 Edison

19) Panda D.K. Nanostructured organic solar cells // University of Wollongong thesis collection. - 2011. PP 1-245.

20) Alam M.A., Ray B. Physics of Organic Solar Cells // NCN Summer School. - 2011.

21) Massachusetts Institute of Technology. // The Future Solar Energy2016, source: https://energy.mit.edu/wp-content/uploads/2015/05/ MITEI-The-Future-of-Solar-Energy.pdf

22) Rural Integrated Development Service-Nepal (RIDS-Nepal). Source: http://www.rids-nepal. org/index.php/Solar_Photo_Voltaic.html

23) University of Maryland Energy Research center. Source: http://www.umerc.umd.edu/ projects/solar08

Paper sent to revision: 05.06.2016.

Paper ready for publication: 14.12.2016. 